\title{
Innovation in Choreography of Leonid Yakobson
}

\author{
Rita Spalva \\ Riga Teacher Training and Educational Management Academy, Riga, Latvia
}

\begin{abstract}
To this day, the name of choreographer Leonid Yakobson is known only among the dance professionals. However, his ballets and dance miniatures, along with the surprising choice of imagery and ballet language, testify that Yakobson has been one of the most outstanding choreographers of the 20th century. The aim of the article is to analyse Leonid Yakobson's most distinguished choreographic works. The chosen theme emphasises inovation in the choreographer's creative work. The chosen research method is analysis of the choreographed works of Leonid Yakobson.The article results show that his art, based on the experience of the Russian classical school of ballet, combines the early 20th century avant-garde principles with influences from the greatest choreographers of the Russian ballet.
\end{abstract}

Keywords: choreographer, Leonid Yakobson, Russian ballet, innovation

\section{Introduction}

The heritage of the choreographer Leonid Yakobson (1904-1975) has a special place in the world of culture. He has composed 30 ballets and nearly two hundred ballet miniatures. He has staged unusual and imaginative characters and was the first choreographer for such unnoticed talent as Galina Ulanova, Maya Plisetskaya, Alla Osipenko, and Mikhail Baryshnikov among others. His numerous publications and the outstanding monograph "Letters to Noverre. Memories and Essays" was written in 1968, and finally published in New York in 2001, all testify that Leonid Yakobson was also a great theoretician. The main feature ringing true to this day is, however, the world of dance, which Jacobson has created, filled with imagination, paradoxes, and challenges.

\section{Innovation in Choreography of Leonid Yakobson}

His choice and interpretation of plot in ballet was always unexpected, surprising with bold solutions that overcame prejudices concerning what constitutes a "non danceable" plot. Despite the very difficult life conditions in which Communist party functionaries tried to hinder his creative work, the master never stopped creating and always hoped that some day his work would reach wider audiences.

Yakobson's most fruitful years coincide with the most totalitarian time in the history of the Soviet Union, where socialist realism was recognized as the only acceptable approach for artistic endeavour. By means of various bans, new ideas in ballet were eliminated and the professional stage allowed only the classical and folk dance performances. Other dance genres (such as modern dance or jazz dance) were not recognized. By doing this, various obstacles were put in the way to such ballet masters as Leonid Yakobson. He was an entirely peculiar

Rita Spalva, Ph.D. in Dance Education, professor at Riga Teacher Training and Educational Management Academy. 
artist with unquenchable imagination and fantasy in both the realms of dance technique and the plot.

Only in 1971, shortly before his death, while being very ill, Leonid Yakobson was finally allowed by the government to stage his troupe "Choreographic Miniatures" ("Хореографические миниатюры") in St Petersburg (Leningrad at the time). His fantasy was unstoppable - in a span of several years, he created dozens of programmes and hundreds of dances. It is a big loss that his work has only partially survived to this day. Many works of his youth have not been filmed. The troupe of his creation "Choreographic Miniatures", existing to this very day, has only partially recovered his work. One reason for this loss is the unique character of his work, which does not lend itself for restoration at all. There are other factors that have hindered the exploration of Yakobson's work. Irina, his widow and partner in artistic endeavour, who had been his assistant and the director of the said troupe for many years, was fired after his death and now resides in the US.

It is likely that her interest in having full control of Yakobson's plays and the anticipation to receive royalties from his work had created the situation that neither theatres of St Petersburg nor Moscow celebrated his hundredth anniversary in an appropriate manner (Аловерт, 2003).

To this day, many ballet professionals and experts are not well versed in the works of the genius master, as they are available only to a limited extent and in a bad quality. It is very important to use the momentum while Yakobson's heritage is still alive in people's memories in order to restore the lost masterpieces and register the knowledge of people who have experienced his work in person.

Leonid Yakobson became interested in dance at 16, a fairly late stage of his life. He was lucky that at the time, Leningrad's ballet school was looking for older boys in order to increase the replenished men's troupe of the Kirov Opera and ballet. Victor Semenov (Семёнов) and Vladimir Ponomaryov (Пономарёв) became his teachers.

\section{Creative Work of Leonid Jacobson}

During his early years of school, he made his first choreographies with Chopin and Grieg's music (Трускиновская, 2010, p. 313). Their peculiar musicality, powerful fantasy, and original language of dance attracted attention (Звёздочкин, 2007, p. 24). After graduation, he continued to produce choreographic miniatures in his native ballet school, however, encountered fierce resistance from Agrypina Vaganova (Ваганова), the director of the school and the main ballet authority at the time. She refused to accept Jacobson's novel compositions. Later in his life, Yakobson continued to emphasize that from early onwards, he had been influenced by famous Mikhail Fokin's (Фокин) plays and his declared position to go "Against the flow" (the title of Fokin's autobiography was "Against the Flow”). He was also influenced by the search of new forms in dance by such forward-looking choreographers from 1920s as Fedor Lopukhov (Лопухов), Kasyan Goleyzovsky (Голейзовский), and Georgre Balanchin (Баланчин; also known in Russia as Balanchivadze).

After conflicts with Vaganova, he set out to look for work in Moscow, Sverdlovsk (now Yakaterinburgh), Moldova, etc.. During this time, he created quite a few small pieces and concert programms. In 1940, he managed to secure the position of a ballet master at the Kazan Opera and Ballet. There, Yakobson created his first large play "Shurale" (“Шурале") using Farid Yarullin's (Яруллин) music (in ballet encyclopaedias the ballet is also known as "Ali-Batir" (“Али-Батыр”). The plot is based on a Tatar fairy tale).

The girl-like bird Suymbike falls in love with a young hunter by name of Ali Batir. The wood spirit Shurale, 
however, rids the girl of her wings and hides her in the deep of the wood. The brave Ali Batir finds and rescues the girl. Shurale and his kingdom are destroyed in a fire. (Балет. Энциклопедия, 1981, p. 596)

Everything was different with this ballet. The many wooden characters each had its own image, not to mention Shurale's own plastics, which displayed a tree branch, a dangerous animal, and a cunning wizard.

Spectators were especially impressed by the scenes of flying birds, which sharply contrasted.

With the other wooden characters, Yakobson composed a separate theme for each group of birds, which was successfully merged into an emotional contra point. "The common drawing of the dance was composed by numerous details. Overlapping movements formed a plastic theme with necessary content and brightness" (Якобсон, 2001, pp. 82-83).

In 1950, the ballet "Shurale" was staged once again at the Leningrad's Kirov theatre and, subsequently, at Moscow's Bolshoi. The ballet was a great success and Leonid Yakobson was awarded Stalin's stipend, the highest recognition in the arts at the time.

Later in 1959, his reflections about the creation of the play and the ballet "Shurale" were summarized under the heading “My Work on the Ballet Shurale” (“Моя работа над балетом „Шурале”), which was only published in the 2001 volume "Letters to Noverre. Memories and Essays" ("Письма Новерру. Воспоминания и эссе»).

The next large format play was created in 1952 at the Maly Opera and Ballet. This was the ballet "Solveig" (with Edvard Grieg's music) about the love of Solveig and Olaph, which is overshadowed by the evil and powerful Ice Maiden. In this ballet, Yakobson consciously rejected new experiments in motion, abiding by traditions of the classical ballet.

Art historian Galyna Dobrovolskaya (Добровольская) analyzed the use of the traditional principles of symphonism in this ballet by saying: “... these are nearly canonical: The main means of expression is a classical dance. Furthermore, it can be said that in this ballet Jacobson's reconciliation with classical tradition becomes a union of a kind" (Добровольская, 1968, p. 60).

Critics praised Yakobson for engaging the classical dance as well as the creation of new poetic characters (Solveig, Ice Maiden), which are so characteristic to the traditional Russian ballet theatre (Gissele, Odetta).

For several years onwards, Jacobson did not receive any commissions from Kirov's theatre. In 1956, the main ballet master Fedor Lopukhov invited Yakobson to stage the ballet "Spartacus" (set to Aram Khachaturian's music). This became a major turn for both the author and the spectators. The play used unexpected forms of expression, which underlined its theatrecallity and monumentalism. There were static poses, the bodies of dancers formed expressed a bas-relief altogether emphasizing a peculiarly grand style of dance.

The innnovation of the play was expressed in its every part - choreography, production, and scenography as well as music. The play turned out to have a happy stage life and continued for nearly 30 years. But as Yakobson's critic Zvezdochkin (Звёздочкин) notes, many stagings of the ballet resulted in the loss of several parts and many expressive details and only few fragments remain to convey the genius of the author (such as Friggys and Spartacus adagion in the last act) (Звёздочкин, 2007, p. 88). Yakobson wrote: "I wrote this play with a style, determined by the antique murals in Louvre, vase paintings in Hermitage and the plastics of the antique greco-roman sculptures” (Звёздочкин, 2007, p. 134).

Yakobson always considered himself to be a balletmaster of Kirov's theatre. Notwithstanding, he was fired from this job several times (for artistic reasons). Between years 1925-1975 he staged eight ballets in the theatre 
(see Table 1).

Table 1

The List of Yakobson's Plays Staged at the Kirov's Opera and Ballet Theatre

\begin{tabular}{|l|l|l|l|}
\hline No. & Year & Title & Composer \\
\hline 1 & 1930 & The Golden Age & Dmitri Shostakovich \\
\hline 2 & 1950 & Shurale & Farid Yarullin \\
\hline 3 & 1956 & Spartacus & Aram Khachaturian \\
\hline 4 & 1959 & Choreographic Miniatures & Different \\
\hline 5 & 1962 & The Bedbug & Dmitri Shostakovich \\
\hline 6 & 1964 & The Twelve & Boris Tishchenko \\
\hline 7 & 1965 & Waltzes & Different \\
\hline 8 & 1967 & Land of Miracles & Isaac Shvarts \\
\hline
\end{tabular}

The names of ballets testify of the author's wide erudition in choosing a plot. Many of his colleagues and dancers admitted that he had encyclopaedic knowledge in arts, yet his main inspiration came from fine arts. He was also admired for his professional skills. Not only was he fanatical about his work, being able to work on a certain idea for years onwards, but also he was able to detect an unprecedented talent among the amateur dancers. In 1969, Yakobson staged a miniature "Vestris" for Michael Barishnikov who had just arrived at Kirov's theatre. He foresaw his grand artistic talent and intuitively predicted his spectacular career in the future (a comparison with "Vestris").

Unexpectedly, he gave the main cast of Zoya Berezkina in the ballet "The Bedbug" to otherwise unknown ballerina Natalya Makarova who, this far, had played character roles.

As Zvezdochkin put it: "Jacobson not only showed the tragic fate of the betrayed Zoya, but seemingly projected Makarova's fate in the future, whose life in the ballet was broken by love and emigration. Thankfully, her artistic career was triumphant” (Звёздочкин, 2007, p. 128).

The choreographic miniature was Jacobson's favourite genre, because he was more than a choreographer, he also had a director's talent,

A miniature is a very demanding, mobile, eloquent, dramaturgically complete form with a character whose plastics are clear. [...]. In a very short time span, it allows to narrate more than full scale ballet plays, as it concentrates and captures spectators attention. (Звёздочкин, 2007, p. 157)

Starting with 1971 when the ballet master was able to form his own troupe, he finally had a chance to create new plays as well as to make a retrospection of his work and to showcase its best parts. The premiere featured a wide programme consisting of four parts: "Classicism. Romanticism", "Rodin", "Russian Miniatures", and "Triptych of Genres". Every part consisted of separate, seemingly unrelated parts, which had a common theme or style of dance. For instance, the first part "Classicism. Romanticism" consisted of seven concerts: "Pas de Trois" (to Rossini); "Pas de Quatre" (to Bellini); "Flight of Tagloni"; "Pas de Deux" (to Mozart); "Medieval Dance with Kisses" (to Prokofiev); "Cachucha" (to Sarasate); and "Dying Swan" (to Saint-Saëns).

Each of these miniatures had its own meaning. Hereby, Jacobson showed his respect to history of ballet and 
its geniuses. By stylistically interpreting the forms of classical dance, he filled them with a new meaning. While "Flight of Tagloni" brings an association of airy romantic ballet, "Cachucha" presents the famous character dances of the 19th century, "Pas de Quatre" is a dedication to Jules Perro, but "The Dying Swan" debates Mikhail Fokin by presenting a swan that has a robust dramatic and a desire to life.

One article is not sufficient to widely engage with Jacobson's heritage. His later years saw even more one act plays and divertissements: "Exercise XX" (to Bach); "Contrasts"; "Travelling Circus"; "Ebony Concerto" (to Stravinsky); "Jewish Wedding" (to Shostakovich); "Symphony of Eternity" (to Tishchenko); "The City" (to Webern); "A Brilliant Divertissement" (to Glinka); "Surprise" (to Haydn); and "Six Pas de Deux" (to Rossini, Chopin, Britten, Honegger, Lehar, and Donizetti) (International Encyclopedia of Dance, 2004, p. 412).

Each spectator who saw these plays could find there a topic that would be dear to him. The author, having lived in St Petersburg in the early 1970s, experienced an unforgettable culture shock already on the first evening of "Choreographic miniatures".

Now, once years have gone by and the author has had a chance to evaluate work in the context of other great 20th century ballet masters, he concludes that the emotional effect of Yakobson's ballets and miniatures have not been surpassed to this day.

One of the fundamental questions that Jacobson tried to answer in his plays and publications was - can contemporary themes be engaged only by using techniques of classical dance. To answer this he created a new choreography, which has not been matched.

It seems that Jacobson's 1971 play "Exercise XX" (to Bach, Swingle Singer), becomes a hymn to dance, where he showed in a poetic fashion how classical dance exercise, known to any dance professional, turns into a whole new choreography. He aptly demonstrated that every canon can be set against an anti-canon. Their synthesis, more importantly, leads to a creation of a new work of art.

\section{Conclusions}

Leonid Jacobson, as an artist with an unsurpassed fantasy, has created his own world of dance. It seems that Jacobson had a capacity to express everything in the language of dance. His ballets and miniatures enlivened murals of the ancient Greece and Rome (ballet "Spartacus"), Mayakovsky set the stage for the satiric poetry (ballet "The Bedbug"), the duets of love were created in the fashion of Rodin's sculptures (Rodin Triptych), a wedding ceremony departed for a long journey from a painting of Marc Schagal ("Jewish Wedding”), Mazarel's graphics and characters from Russian folklore all came to life. Jacobson considered and proved in practice that any theme could be turned into a dance. Today, we can only ponder if Jacobson has become a ballet reformer along Fokin or Bejart. The author would like to argue that Yakobson's influence upon the development of choreographic thought would have been very great had his work come to attention of the world at the time when they were staged - in the middle of the 20th century. However, those ballet masters who had a chance to get to know Jacobson's work learned the most important thing - the freedom of a creative spirit, artistic courage, letting go of clichés and prejudices. It is for this reason that Boris Eifman, whose discipleship is set around the early 1970s, called Leonid Jacobson his Great Teacher.

\section{References}


Cohen, S. J. (Ed.). (2004). International encyclopedia of dance. Oxford: Oxford University Press.

Аловерт, Н. (2003). Великие хореографы: Леонид Якобсон. Вариации на тему (Variations on a Theme). Retrieved from N3 www.russiban-bazaar.com/ru/content/4473.htm

Балет.Энииклопедия (The Ballet Encyclopedia) (1981). Москва:Совтская энциклопедия .

Добровольская, Г. (1968) Балетмейстер Леонид Якобсон (The Ballet Master Leonid Yakobson). Leningrad: Лениниград.

Зайдельсон, В., \& Якобсон, И. Д. (1993). Беседы о Леониде Якобсоне, или, необходимый разговор и письмо,посланное вслед (Talks about Leonid Yakobson or the Necessary Conversation and the Letter That Followed). Saint Petersburg: Максима.

Звёздочкин, В. А. (2011). Новаторские принципы хореографических интерпретаций Леонида Якобсона 1960-x (Innovative Principles of Choreographic Interpretations by Leonid Yakobson in 1960s). Общество.Среда.Развитие, 3.

Звёздочкин, В. А. (2007). Творчество Леонида Якобсона (Creative Work of Leonid Yakobson). Saint Petersburg: Saint Petersburg State University for the Humanities.

Звёздочкин, В. А. (2010). Спор об истине,или парадоксы танияа в хореографических шедеврах Леонида Якобсона Шурале(1950) и Спартак (1953) (The Dispute about the Truth, or the Paradoxes of Dance in Choreographic Masterpieces Shurale (1950) and Spartacus by Leonid Yakobson). Известия Росийского государственного педагогического университета им, 120.

Недбай, Ф. (2004). Леониду Якобсону посвящается (Dedicated to Leonid Yakobson). Петербургский театральный журнал, $6(35)$.

Трускиновская, Д. (2010). Сто великих мастеров балета (100 Great Ballet Masterpieces). Москва: ВЕЧЕ.

Якобсон, Л. (2001). Письма Новеру. Воспоминаия и эссе (Letters to Noverre. Memories and Essays). New York: Hermitage Publishers. 